\title{
Care plans for \\ native and prosthetic joint septic arthritis, and acute hematogenous and chronic osteomyelitis
}

\author{
Stephen D Shafran MD FRCPC and \\ The Septic Arthritis/Osteomyelitis Outpatient Intravenous Antibiotic Therapy Working Group*
}

\begin{abstract}
S Shafran and The Septic Arthritis/Osteomyelitis Outpatient Intravenous Antibiotic Therapy Working Group. Care plans for native and prosthetic joint septic arthritis, and acute hematogenous and chronic osteomyelitis. Can J Infect Dis 2000;11(Suppl D):34D-40D.
\end{abstract}

The current paper presents care plans for the treatment of septic arthritis of native and prosthetic joints, as well as for acute hematogenous and chronic osteomyelitis. A nursing care plan for septic arthritis and osteomyelitis is included, along with pathogen-specific therapy for common pathogens, including Gram-positive and Gram-negative cocci.

Key Words: Acute hematogenous osteomyelitis; Care plan; Chronic osteomyelitis; Native joint septic arthritis; Prosthetic joint septic arthritis

Plans de soins pour l'arthrite articulaire septique et l'ostéomyélite hématogène aiguë et chronique touchant des articulations natives et des prothèses

RÉSUMÉ : Le présent article propose des plans de soins pour le traitement de l'arthrite septique touchant les articulations natives ou des prothèses et l'ostéomyélite hématogène aiguë et chronique. Un plan de soins infirmiers pour le traitement de l'arthrite septique et de l'ostéomyélite y est inclus, de même que des suggestions d'antibiothérapie spécifiques à certains agents pathogènes courants dont les cocci Gram positif et Gram négatif.

*Mr Luc Bergeron, Centre hospitalier universitaire de Québec, Ste-Foy, Québec; Dr Ross Pennie, McMaster University Medical Centre, Hamilton, Ontario; Ms Alison Alleyne, Mount Sinai Hospital, Toronto, Ontario; Mr Jim Oxsley, Moose Jaw Union Hospital, Moose Jaw, Saskatoon; Dr John Gill, Southern Alberta Human Immunodeficiency Virus Clinic, Calgary, Alberta; Dr Christopher Wong, Royal Columbian Hospital, New Westminster, British Columbia; Ms Carol DeLorme, Hôpital Charles Lemoyne, Greenfield Park, Québec; Ms Kristi Hallett, Foothills Hospital, Calgary, Alberta; Mr Don Hamilton, British Columbia Children's Hospital, Vancouver, British Columbia; Dr Andy Pattullo, Kelona General Hospital, Winnipeg, Manitoba; Ms Leilani Todorovic, Burnaby General Hospital, Burnaby, British Columbia; Ms Maria Lazaruk, St Boniface General Hospital, Winnipeg, Manitoba; Ms Carolyn Doroshuk, Misericordia Hospital, Edmonton, Alberta

Correspondence: Dr Stephen D Shafran, Division of Infectious Diseases, Department of Medicine, University of Alberta, H-Site, 10240-112 Street NW, Edmonton, Alberta T6G 2B7. Telephone 780-407-7137, fax 780-407-8077, e-mailsshafran@ualberta.ca 


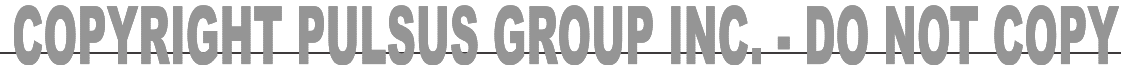

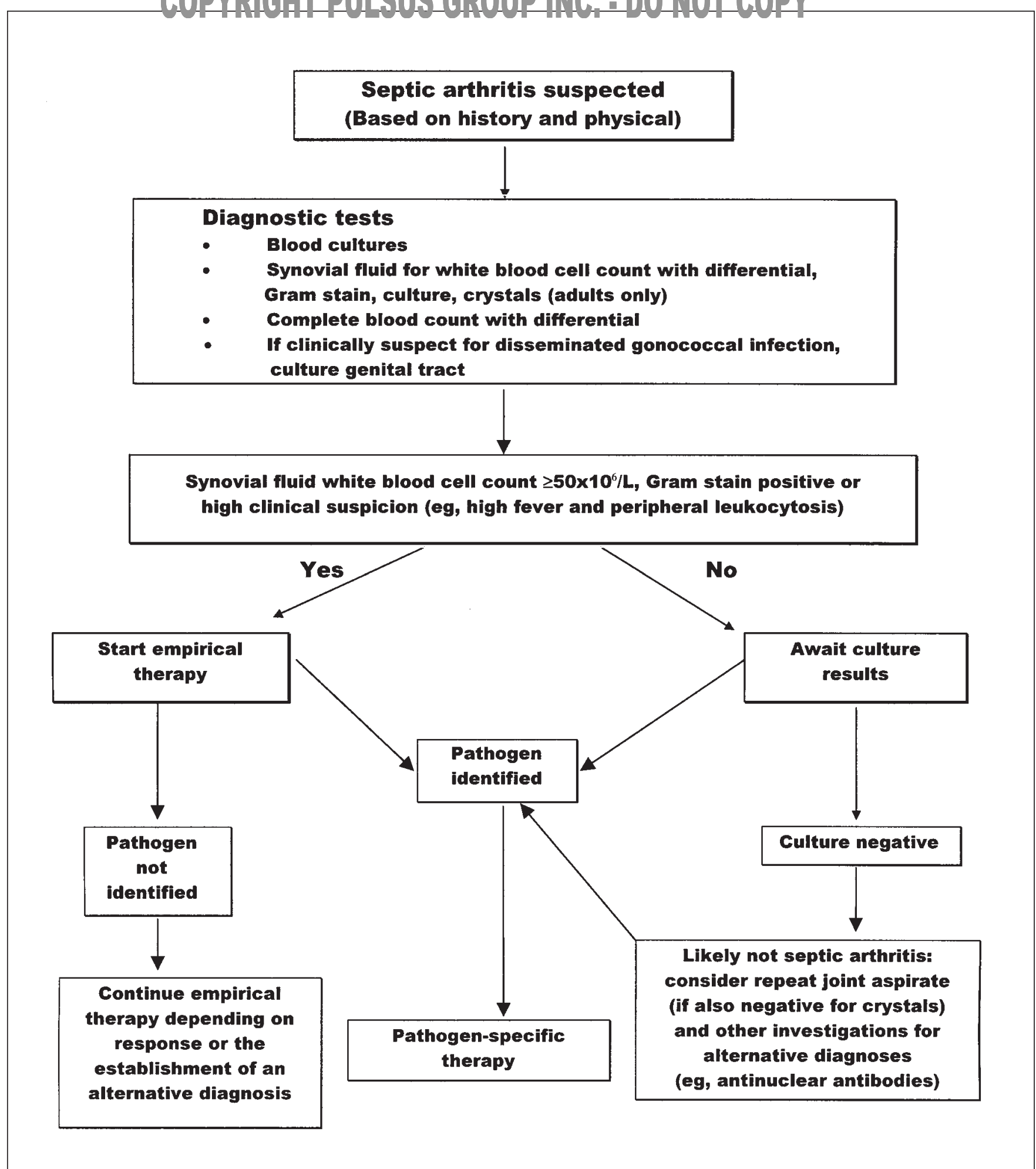

Figure 1) Care plan for septic arthritis of a native joint

\section{SEPTIC ARTHRITIS OF A NATIVE JOINT}

Septic arthritis of a native joint is the prevalent form of septic arthritis (1). The most common predisposing condition of this infection in adults is rheumatoid arthritis (2), and any monoarticular exacerbation of arthritis in a patient with rheumatoid arthritis must be investigated for infection. The care plan for this septic arthritis of a native joint is outlined in Figure 1. The most common pathogens are methicillinsusceptible Staphylococcus aureus followed by streptococci (2); therefore, the usual empirical therapy is cloxacillin 


\section{Septic arthritis suspected (Based on history and physical)}
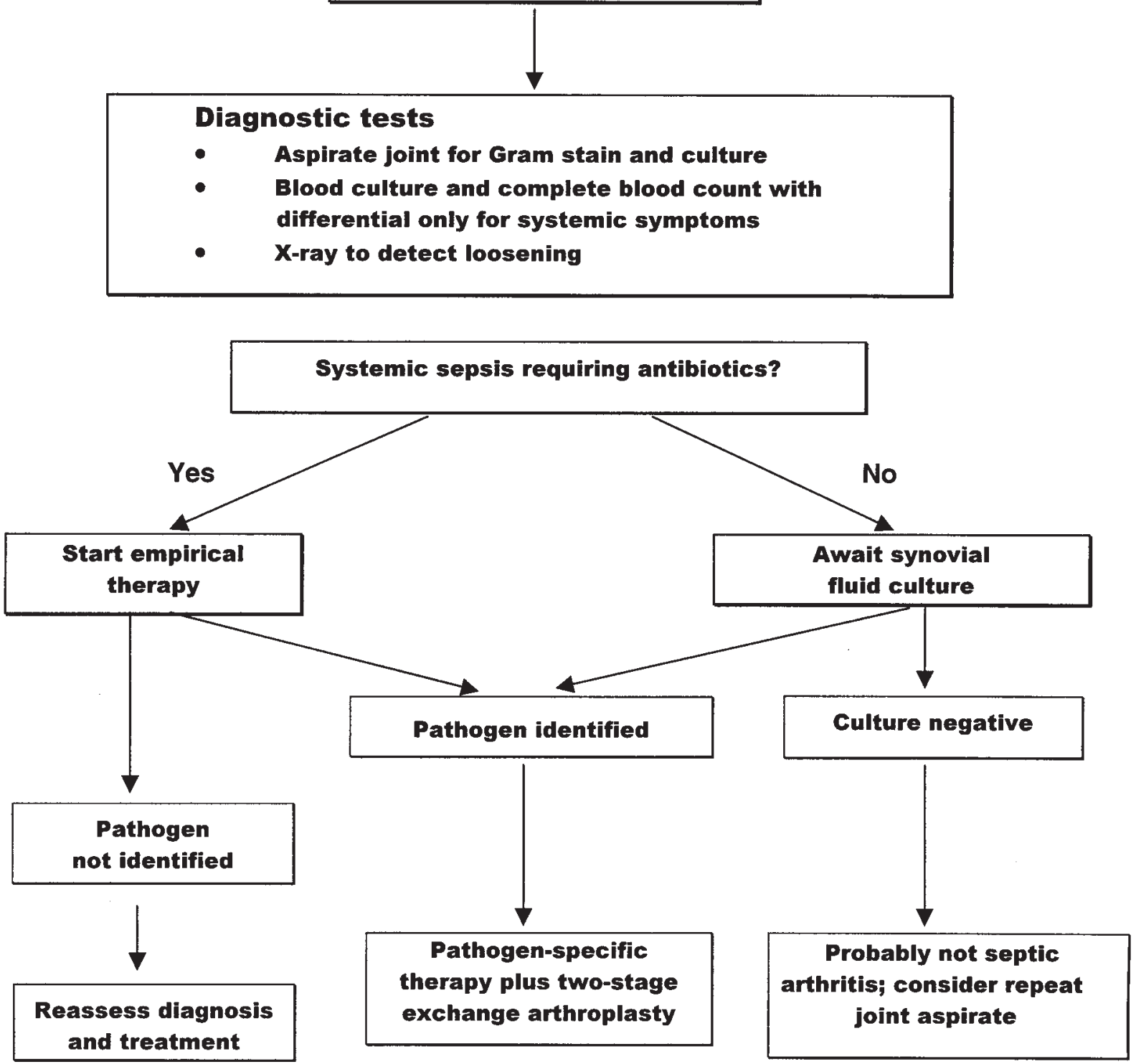

Figure 2) Care plan for septic arthritis of a prosthetic joint

or cefazolin. Pending culture results, some clinicians add gentamicin in selected cases to eradicate Enterobacteriaceae, such as Escherichia coli, Klebsiella species and Enterobacter species (3). However, de novo Gram-negative rod infections are not common in the immunocompetent host. In penicillinallergic patients, vancomycin or clindamycin are the agents of choice. The usual duration of therapy is three to four weeks (4). In addition to antibiotics, joint drainage should be performed in all cases. Usually this can be accomplished by aspirations, but sometimes open surgical drainage must be employed if pus is too thick or if the infection involves the hip joint. In children, initial parenteral antibiotic therapy is usually stepped down to oral therapy if there is a known susceptible organism and if the infection is resolving well clinically.

The care pathway (Figure 1) does not apply to gonococcal arthritis, which presents differently and is easy to distinguish clinically from septic arthritis due to other pathogens. Gonococcal arthritis usually requires only three days of intravenous antibiotics (usually ceftriaxone) followed by seven days of oral antibiotics. 


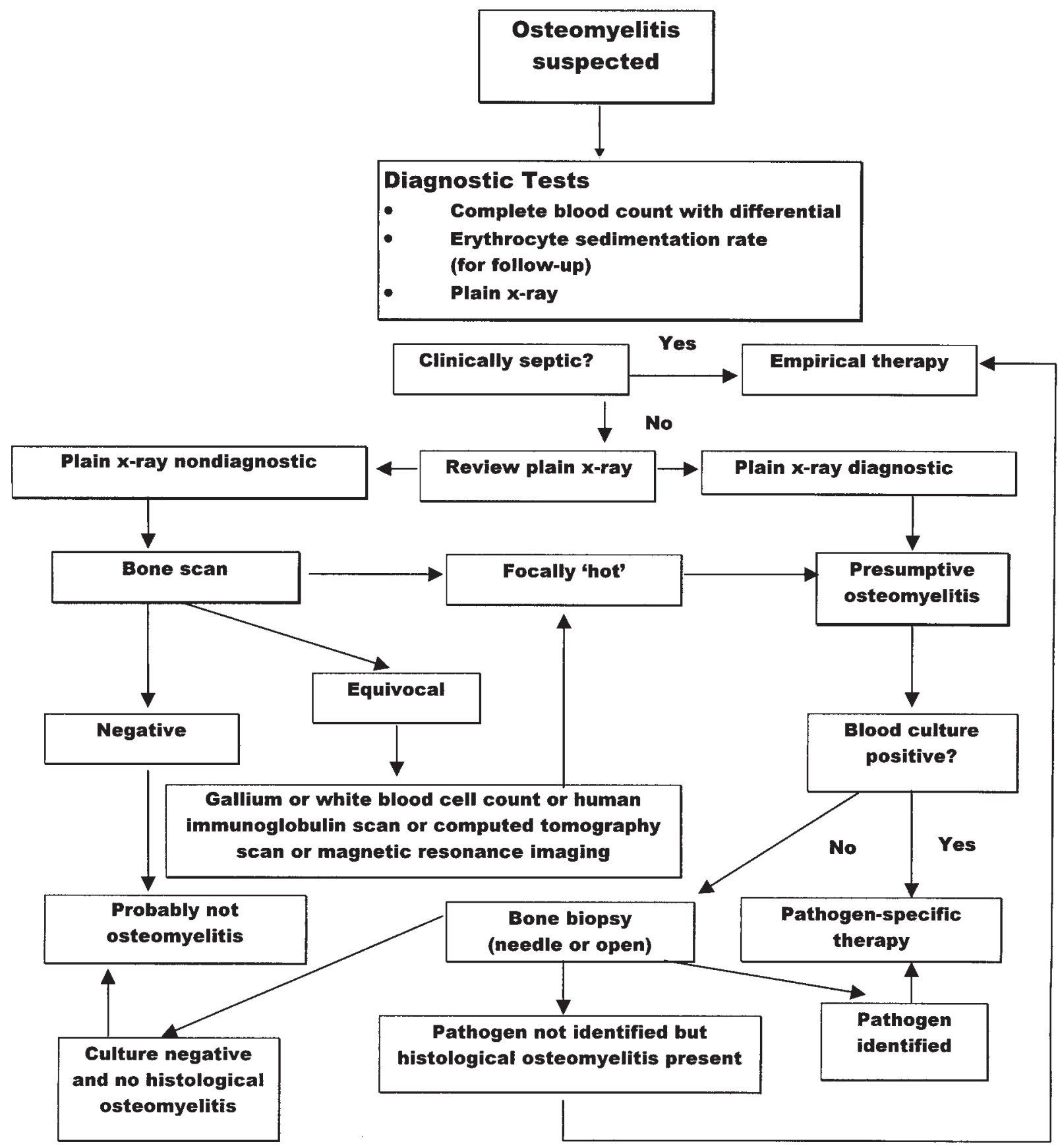

Figure 3) Care plan for hematogenous osteomyelitis

\section{SEPTIC ARTHRITIS OF A PROSTHETIC JOINT}

The clinical signs and symptoms for the patient with an infected prosthetic joint may be insidious; for example, the patient may have pain as the major complaint, instead of fever or other features of sepsis. Figure 2 depicts the steps to follow when caring for a patient with an infected prosthetic joint. The most important diagnostic procedure is aspiration of the involved joint. Empirical therapy should be avoided if at all possible so that reliable cultures can be taken and susceptibility testing can be performed on any isolates. The most common pathogen is coagulase-negative staphylococcus (5). The minimum duration of therapy is six weeks, which usually 


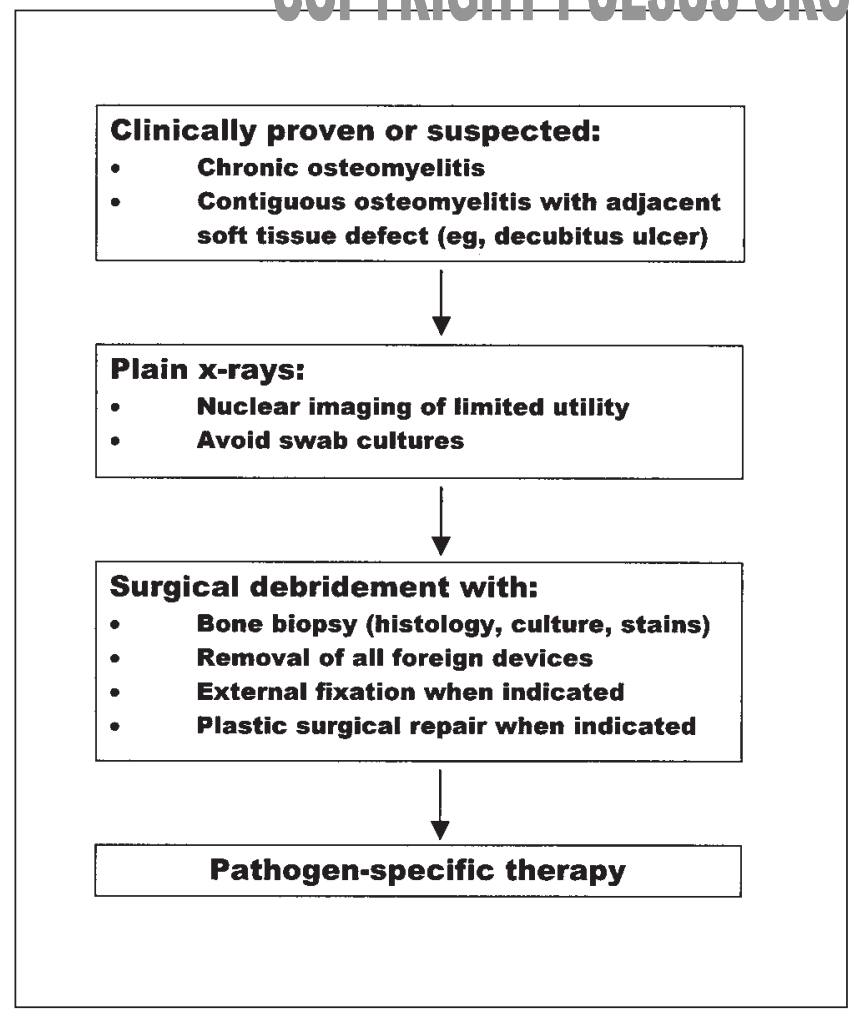

Figure 4) Care plan for chronic osteomyelitis

includes a short hospital stay and outpatient intravenous antibiotic therapy using a peripherally inserted central catheter. A two-stage exchange arthroplasty is the usual surgical strategy (6). Medical therapy alone almost always fails. If the erythrocyte sedimentation rate and the C-reactive protein levels are high to begin with, further monitoring these parameters may be used as a rough index of response of the infection, because reculturing the joint by reaspiration is not usually conducted until just before the second-stage arthroplasty.

\section{HEMATOGENOUS OSTEOMYELITIS}

Hematogenous osteomyelitis may present either in the acute stage, as is usual for small children, or in the chronic stage. The care plan for hematogenous arthritis is presented in Figure 3. For a patient in the acute stage, it is important to remember that plain $\mathrm{x}$-rays do not exclude the diagnosis of osteomyelitis. A technetium-labelled bone scan is much more sensitive in the early stages. The best microbiological diagnostic test for children is blood culture, and $S$ aureus is by far the most common isolate $(7,8)$. Cloxacillin, therefore, is the usual agent of choice, but cefazolin can also be used. In children with staphylococcal or streptococcal osteomyelitis, oral step-down therapy is usually preferred once the acute stage of the infection is under control (9). The usual duration of therapy for children is four weeks, while the usual duration of intravenous therapy for adults is six weeks with a peripherally inserted central catheter. In adults with infection caused by Gram-negative rods, an oral fluoroquinolone such as ciprofloxacin, 500 to $750 \mathrm{mg}$ bid, is usually preferred.
NAGi: DO NOT COPY

Septic arthritis or osteomyelitis nursing care plan

\begin{tabular}{|c|c|c|}
\hline $\begin{array}{l}\text { Nursing diagnosis } \\
\text { Nursing goal } \\
\text { Outcome criteria }\end{array}$ & \multicolumn{2}{|c|}{$\begin{array}{l}\text { Potential for deterioration or adverse effects } \\
\text { No deterioration or adverse effects } \\
\text { Deterioration or adverse effects resulting in a } \\
\text { change in treatment }\end{array}$} \\
\hline ursing interventi & & \\
\hline & $\begin{array}{l}\text { Nursing assessment } \\
\text { - Assess joint or wound } \\
\text { for colour, swelling, } \\
\text { pain, decreased } \\
\text { range of motion and } \\
\text { drainage } \\
\text { - Record vital signs } \\
\text { - Assess intravenous } \\
\text { device and skin exit site } \\
\text { - Ask about skin rash and } \\
\text { other adverse events of } \\
\text { the medication and } \\
\text { confirm presence if } \\
\text { mentioned } \\
\text { - Assess adherence to } \\
\text { regimen: drug, } \\
\text { intravenous device } \\
\text { maintenance, activities } \\
\text { of daily living } \\
\text { (especially mobility), } \\
\text { laboratory monitoring }\end{array}$ & $\begin{array}{l}\text { Nurse alert } \\
\text { - Increased swelling, } \\
\text { increased redness, } \\
\text { increased pain, } \\
\text { decreased range of } \\
\text { motion, adverse } \\
\text { change in wound } \\
\text { drainage } \\
\text { - Fever } \geq 38^{\circ} \mathrm{C} \\
\text { - Redness, swelling } \\
\text { or pain at } \\
\text { intravenous site; } \\
\text { device malfunction } \\
\text { - Skin rash; other } \\
\text { significant adverse } \\
\text { events }\end{array}$ \\
\hline
\end{tabular}

Nursing diagnosis Potential for deterioration or adverse effect Nursing goal No deterioration or adverse effects significant adverse 
TABLE 2

Pathogen-specific therapy: Antibiotics of choice for common Gram-positive cocci

\begin{tabular}{|c|c|c|}
\hline \multirow[b]{2}{*}{ Organism } & \multicolumn{2}{|c|}{ Antibiotic treatment* } \\
\hline & Adult dose & Paediatric dose \\
\hline $\begin{array}{l}\text { Staphylococcus aureus, } \\
\text { methicillin susceptible }\end{array}$ & $\begin{array}{l}\text { Cloxacillin } 2 \mathrm{~g} \text { (every } 6 \mathrm{~h} \text { ) or } \\
\text { Cefazolin } 2 \mathrm{~g} \text { (every } 8 \text { h) }\end{array}$ & $\begin{array}{l}\text { Cloxacillin } 50 \mathrm{mg} / \mathrm{kg}(\text { every } 6 \mathrm{~h})^{+} \text {or } \\
\text { Cefazolin } 30 \mathrm{mg} / \mathrm{kg}(\text { every } 8 \mathrm{~h})^{+}\end{array}$ \\
\hline For cephalosporin allergy & $\begin{array}{l}\text { Vancomycin } 1 \mathrm{~g} \text { (every } 12 \mathrm{~h} \text { ) or } \\
\text { Clindamycin } 600 \mathrm{mg} \text { (every } 8 \mathrm{~h} \text { ) }\end{array}$ & $\begin{array}{l}\text { Vancomycin } 15 \mathrm{mg} / \mathrm{kg} \text { (every } 8 \text { to } 12 \mathrm{~h} \text { ) or } \\
\text { Clindamycin } 10 \text { to } 13 \mathrm{mg} / \mathrm{kg} \text { (every } 8 \mathrm{~h})^{+}\end{array}$ \\
\hline$S$ aureus, methicillin resistant & Vancomycin $1 \mathrm{~g}$ (every $12 \mathrm{~h}$ ) & Vancomycin 15 mg/kg (every 8 to 12 h) \\
\hline Streptococcus species & $\begin{array}{l}\text { Penicillin G } 3 \text { to } 4 \mathrm{MU} \text { (every } 12 \mathrm{~h} \text { ) or } \\
\text { Cefazolin } 2 \mathrm{~g} \text { (every } 8 \mathrm{~h} \text { ) }\end{array}$ & $\begin{array}{l}\left.\text { Penicillin } 50,000 \mathrm{U} / \mathrm{kg}^{(\text {every }} 6 \mathrm{~h}\right)^{\dagger} \text { or } \\
\text { Cefazolin } 30 \text { to } 50 \mathrm{mg} / \mathrm{kg}^{\dagger} \text { (every } 8 \mathrm{~h} \text { ) }\end{array}$ \\
\hline For cephalosporin allergy & $\begin{array}{l}\text { Vancomycin } 1 \mathrm{~g} \text { (every } 12 \mathrm{~h} \text { ) or } \\
\text { Clindamycin } 600 \mathrm{mg} \text { (every } 8 \mathrm{~h} \text { ) }\end{array}$ & $\begin{array}{l}\text { Vancomycin } 15 \mathrm{mg} / \mathrm{kg} \text { (every } 12 \mathrm{~h} \text { ) or } \\
\text { Clindamycin } 10 \text { to } 13 \mathrm{mg} / \mathrm{kg}(\text { every } 8 \mathrm{~h})^{+}\end{array}$ \\
\hline For once daily therapy & Ceftriazone 2 g (every 24 h) & Ceftriazone 50 mg/kg (every 24 h) \\
\hline Enterococcus species & $\begin{array}{l}\text { Ampicillin } 2 \mathrm{~g}(\text { every } 6 \mathrm{~h})^{\ddagger} \text { plus } \\
\text { Bentamicin } 1 \mathrm{mg} / \mathrm{kg}(\text { every } 8 \mathrm{~h})^{\S, * *} \text { (if synergistic in vitro) }\end{array}$ & $\begin{array}{l}\text { Ampicillin } 50 \mathrm{mg} / \mathrm{kg} \text { (every } 6 \mathrm{~h} \text { ) plus } \\
\text { Gentamicin } 1 \mathrm{mg} / \mathrm{kg} \text { (every } 8 \mathrm{~h} \text { ) }\end{array}$ \\
\hline $\begin{array}{l}\text { For penicillin allergy or } \\
\text { ampicillin resistance }\end{array}$ & $\begin{array}{l}\text { Vancomycin } 1 \mathrm{~g} \text { (every } 12 \mathrm{~h} \text { ) plus } \\
\text { Gentamicin } 1 \mathrm{mg} / \mathrm{kg} \text { (every } 8 \mathrm{~h} \text { )s,** (if synergistic in vitro) }\end{array}$ & $\begin{array}{l}\text { Vancomycin } 15 \mathrm{mg} / \mathrm{kg} \text { (every } 12 \mathrm{~h} \text { ) plus } \\
\text { Gentamicin } 1 \mathrm{mg} / \mathrm{kg} \text { (every } 8 \mathrm{~h} \text { ) }\end{array}$ \\
\hline
\end{tabular}

* May need to adjust doses based on renal function or size in adults. ${ }^{\dagger}$ It is usually possible to switch from intravenous to oral antibiotics in children in the first week of therapy for streptococcal infections and methicillin-susceptible staphylococcal infections. Some clinicians prefer to measure serum bactericidal concentrations when switching to oral therapy. ${ }^{\ddagger}$ Can use penicillin $\mathrm{G}$ instead of ampicillin if synergistic with aminoglycosides. ${ }^{\S}$ Substitute streptomycin for gentamicin if synergistic and gentamicin-resistant. Consider fluoroquinolone for synergy if resistant to both gentamicin and streptomycin. ${ }^{* *}$ More data exist on conventional dosing than on the once daily dosing of aminoglycosides for enterococcal infections

TABLE 3

Pathogen-specific therapy: Antibiotics of choice for common Gram-negative cocci

\begin{tabular}{|c|c|c|}
\hline Organism & \multicolumn{2}{|c|}{ Antibiotic treatment* } \\
\hline $\begin{array}{l}\text { Haemophilus influenzae, } \\
\text { ampicillin susceptible }\end{array}$ & Ampicillin 2 g (every 6 h) & Ampicillin 50 mg/kg (every 6 h) \\
\hline $\begin{array}{l}H \text { influenzae, ampicillin } \\
\text { resistant }\end{array}$ & $\begin{array}{l}\text { Cefuroxime } 1.5 \mathrm{~g} \text { (every } 8 \mathrm{~h} \text { ) or } \\
\text { Ceftriaxone } 1 \text { to } 2 \mathrm{~g} \text { (every } 24 \mathrm{~h} \text { ) or } \\
\text { Cefotaxime } 1 \text { to } 2 \mathrm{~g} \text { (every } 8 \mathrm{~h} \text { ) }\end{array}$ & $\begin{array}{l}\text { Cefuroxime } 50 \mathrm{mg} / \mathrm{kg} \text { (every } 8 \mathrm{~h} \text { ) or } \\
\text { Ceftriaxone } 50 \mathrm{mg} / \mathrm{kg} \text { (every } 24 \mathrm{~h} \text { ) or } \\
\text { Cefotaxime } 50 \mathrm{mg} / \mathrm{kg} \text { (every } 8 \mathrm{~h} \text { ) }\end{array}$ \\
\hline
\end{tabular}

* May need to adjust doses based on renal function or size in adults. 'If possible, avoid these cephalosporins if pathogen is Serratia species, Enterobacter species, Providencia species, Morganella species or Citrobacter freundii, due to the possibility of derepressing latent cephalosporinase

\section{NURSING CARE PLAN FOR SEPTIC ARTHRITIS OR OSTEOMYELITIS}

Patients often receive a portion (usually the majority) of intravenous therapy in an outpatient program. In these cases, home care nurses clinically monitor the patients and the intravenous devices, often every day or every other day. A nursing care plan is presented in Table 1 . The physician should follow the progress of these patients approximately every week during the intravenous treatment.

\section{PATHOGEN-SPECIFIC THERAPY FOR COMMON PATHOGENS}

Variability exists in the therapy of septic arthritis and osteomyelitis. Therapy depends on the pathogen isolated and patient-related specifics that dictate a regimen (eg, known allergies or drug intolerance). Tables 2 and 3 list the antibiotics of choice for the paediatric and adult age groups for some of the most common pathogens, with alternative regimens for patients with penicillin allergy. 


\section{REFERENCES}

\section{COPYRIGHT PULSUS GROUP INC, D DO NOT COPY}

1. Goldenberg D. Septic arthritis. Lancet 1998;351:197-202.

2. Goldenberg DL, Reed JI. Bacterial arthritis. N Engl J Med 1985;312:764-71.

3. Hamed KA, Tam JY, Prober CG. Pharmacokinetic optimization of the treatment of septic arthritis. Clin Pharmacokinet 1996;21:156-63.

4. Syrogiannopoulos GA, Nelson JD. Duration of antimicrobial therapy for acute suppurative osteoarticular infections. Lancet 1988;i:37-40.

5. Gillespie WJ. Prevention and management of infection after total joint replacement. Clin Infect Dis 1997;25:1310-7.

6. Garvin KL, Hanssen AD. Infection after total hip arthroplasty: past, present, and future. J Bone Joint Surg Am 1995;77:1576-88.

7. Lew DP, Waldvogel FA, Osteomyelitis. N Engl J Med 1997;336:999-1007.

8. Haas DW, McAndrew MP. Bacterial osteomyelitis in adults: evolving considerations in diagnosis and treatment. Am J Med 1996;101:550-61.

9. Peltola H, Unkoila-Kalliol, Kaliol MJT. Finnish Study Group. Simplified treatment of acute staphylococcal osteomyelitis of childhood. Pediatrics 1997;99:846-50.

10. Mackowisk PA, Jones SR, Smith JW. Diagnostic value of sinus tract cultures in chronic osteomyelitis. JAMA 1978;239:2772-5. 


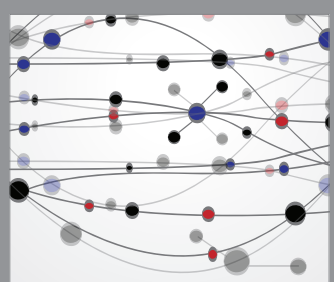

The Scientific World Journal
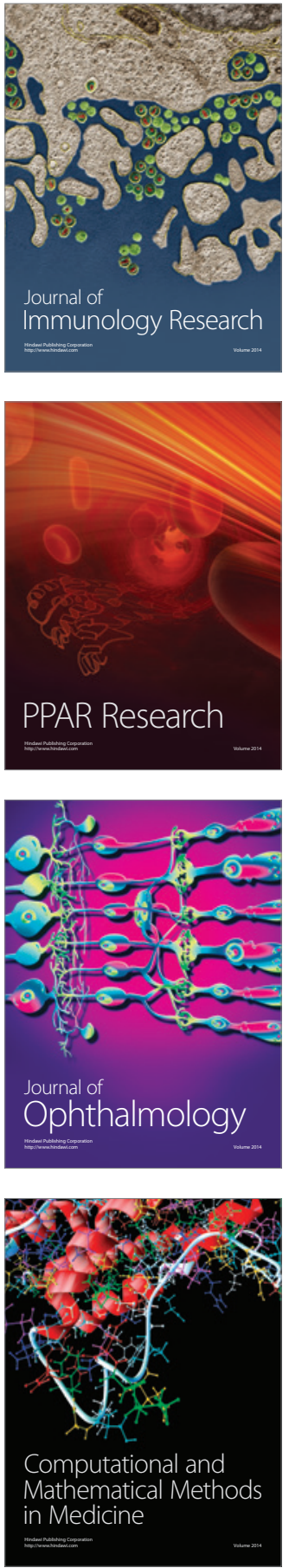

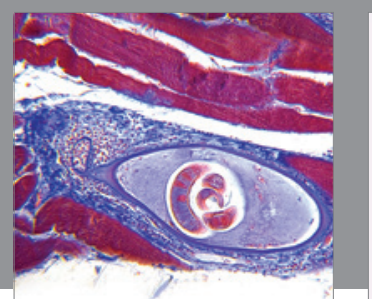

Gastroenterology Research and Practice

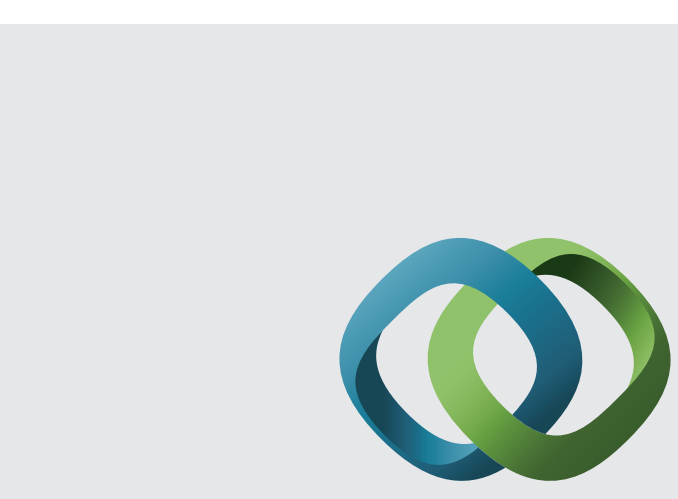

\section{Hindawi}

Submit your manuscripts at

http://www.hindawi.com
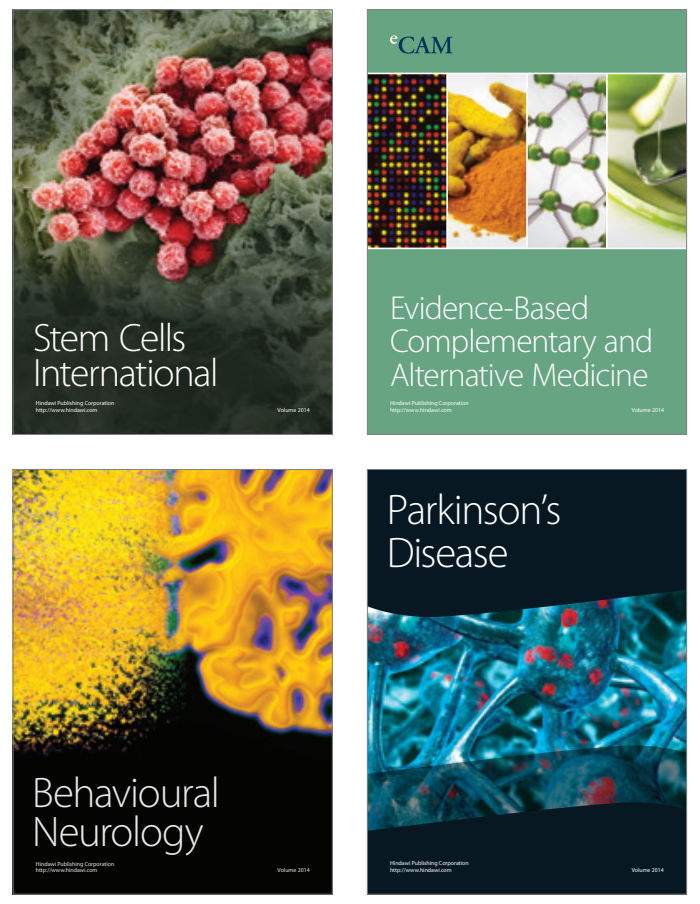
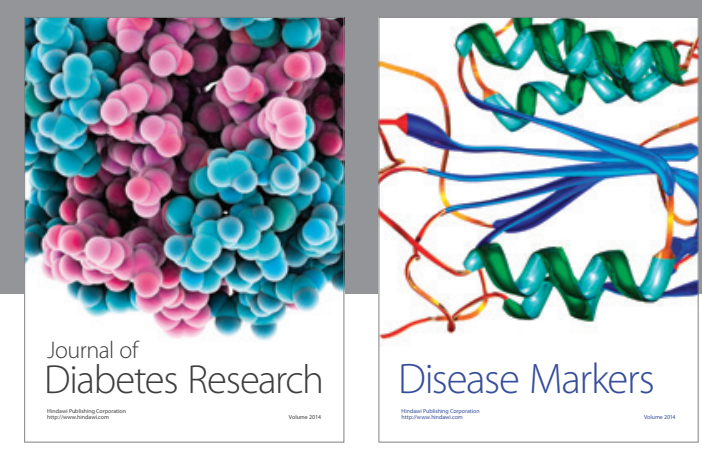

Disease Markers
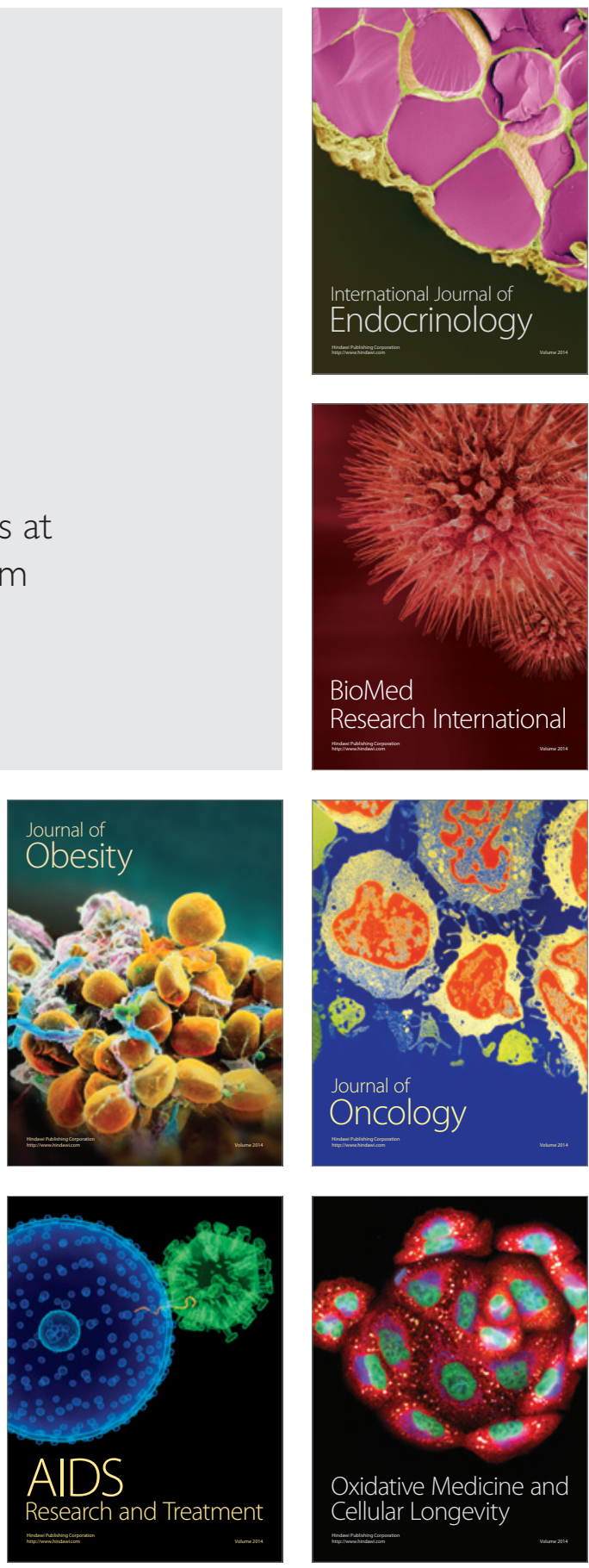